\title{
SOCIAL AND ECONOMIC EFFECTS OF RHEUMATIC DISEASES IN A MINING POPULATION
}

\author{
BY \\ J. A. D. ANDERSON, J. J. R. DUTHIE, AND B. P. MOODY \\ Empire Rheumatism Council, Industrial Survey Unit, Northern General Hospital, Edinburgh
}

It is customary to attribute the first use of the term rheumatism to the French physician, Baillou, in the 16th century, but anthropological studies indicate that afflictions of this type have been in existence since before the dawn of history. In spite of their antiquity, however, it is only in the past 50 years that the importance of the rheumatic group of diseases has become generally recognized.

One reason why illnesses from rheumatic causes have become more prominent may be that the control of spread of the infectious diseases by preventive measures and their successful treatment with antibiotics have altered the patterns of morbidity. This has led to a relatively greater prevalence of the non-infectious diseases of which the rheumatic group forms an important part. Concurrently with this change in emphasis, however, has come the concentration of industry and with this the need for some form of commercial or national insurance to protect workers against the economic privation caused by ill-health. Those concerned with the organization of such insurance systems have come to examine the two great causes of economic hardship, namely, absence through sickness and premature retirement.

Kahlmeter (1923), who was among the first to use the information available from such insurance sources, showed that articular rheumatism was responsible for the retirement of 9 per cent. of insured workers who gave up work prematurely. A report by the Ministry of Health (1924) emphasized the importance of rheumatism as a cause of sickness absence, indicating that nearly one-sixth of all incapacity in the industrial population was attributable to rheumatic disease. The Department of Health for Scotland (1945) also emphasized the relative importance of rheumatism in causing disability and suggested that time lost because of rheumatism might vary with occupation. Thus it was shown that, whereas 4.7 per cent. of miners were incapacitated in any given year because of rheumatism, the rate was only $2 \cdot 6$ per cent. for metal workers.

The Ministry of Pensions and National Insurance Digest of Statistics (1956) indicates that in 1953-54음 rheumatic complaints caused the loss of some 27 million working days in the United Kingdom Interest in the importance of rheumatism as a cause of sickness absence has also been aroused in America 3 In one particular industry with several different@ occupations and skills in New York, Brown andLingg (1961) found that 15 per cent. of all employeses sought medical advice because of rheumatism during a period of 12 months, and that 9 per cegto of the total loss of time in the year was due tos rheumatism.

These observations clearly indicate that rheumation complaints are responsible for much of the certified $Q$ incapacity that occurs in industry, but in order to $\vec{B}$ explore their other social and economic effects the 3 overall prevalence of complaints in the community? must be ascertained.

In a survey in the industrial town of Leigh, of a one-in-ten sample of males aged 15 years and over, Kellgren, Lawrence, and Aitken-Swan (1953) found the prevalence of rheumatic symptoms at the time of interview to be 19 per cent. This figure was increased to 31 per cent. by including all those who admitted having had rheumatism at any time? within 5 years of the interview.

Before this, Lawrence and Aitken-Swan (1952) had compared miners with other males of working age. They showed that the prevalence of symptoms increased with age and that there was little difference in the prevalences by age for the two groups of workers. A notable exception was found during the fourth decade, in which the complaint rate among miners was 35 per cent. compared with 26 per cent $\$$ in non-miners.

Relying on information provided from memory 
by those being interviewed, Lawrence and AitkenSwan found that 13.2 per cent. of miners lost one week or more because of rheumatism in the 5 -year period, whereas only 7.6 per cent. of non-miners lost one week or more during the same time. These crude rates were supported by findings in all age groups. A similar trend (5.5 per cent. miners and 1.9 per cent. non-miners) was demonstrated for those who had been absent from work with rheumatic complaints for 3 months or more during the previous 5 years.

The amount of time lost through rheumatism in different occupations has been discussed by Duthie and Anderson (1962), who also indicated that the difference in time lost through rheumatism varied from one group of workers to another.

Although considerable attention has been devoted to the prevalence of rheumatism in the community as a whole, relatively little note has been taken of the occupational and environmental factors which may contribute to the onset of rheumatic complaints or which may aggravate those which already exist. For this reason, and also with a view to studying the social and economic effects of rheumatism, the Empire Rheumatism Council has sponsored the formation of a small Industrial Survey Unit, based on Edinburgh University.

The broad aims of the Unit are:

(1) To gain a more accurate picture of the prevalence of rheumatism in specific industries than can be derived from the analysis of statistical records.

(2) To estimate the financial implications to both employee and employer.

(3) To investigate the importance of conditions at work which may predispose to or aggravate rheumatic complaints.

(4) To examine industrial processes with a view to advising the employers how the incidence of such complaints may be reduced.

(5) To designate the occupations which may be efficiently performed by workers already partially disabled by rheumatism.

As a first step it was decided to carry out a study similar to that of Lawrence and Aitken-Swann. It was hoped that this might reveal some similarities between the prevalence of rates obtained by the two sets of observers and provide further information on the prevalence of rheumatism in miners. In addition, this paper seeks to report on the sickness patterns of those with rheumatic symptoms and to assess the effects on their economic status.

\section{Background}

On the advice of the Scottish Headquarters of the National Coal Board and with the agreement of the
National Union of Mineworkers, a colliery of average size was selected.

This colliery is situated on the south side of Edinburgh and employs an average of 970 workers. The workings, which are about half to threequarters of a mile from the shaft bottom, are reasonably dry and the height at the coal face is $2 \frac{1}{2}$ to 3 feet.

Coal production has been carried on for 56 years and averaged 1,100 tons a day in 1961. The employees reside within a radius of 8 miles, many having been transferred from other collieries in the neighbourhood which have been closed down.

Four types of workers are considered in the present study:

(1) Strippers, who remove the coal from the seam. Each is expected to clear an area of coal face about 27 feet long and $2 \frac{1}{2}$ feet high to a depth of $4 \frac{1}{2}$ feet during the course of a shift.

(2) Brushers, who move the working area forward by the same depth of $4 \frac{1}{2}$ feet. At the same time they pack stones and rubble into the cavities adjacent to the advancing road from which the coal has been removed.

(3) Underground haulage workers, who are responsible for the supervision of the conveyor belts and coal trucks by which the coal is carried from the face to the bottom of the shaft.

(4) Surface workers, who are responsible for the haulage of the trucks from the top of the shaft, and sorting, working, and handling the coal until it is on the lorries. They also supervise the disposal of rubble on to the slag heap or bing.

Strippers and brushers are classed as face workers (F.W.) because their conditions of work are essentially the same in terms of physical labour, posture, and risk of injury.

Underground haulage workers and those employed on the surface are grouped together as non-face workers (N.F.W.). In general these men can stand erect at their work and, although effort is required intermittently, they do not have to handle large quantities of coal or rock for prolonged periods.

For the purpose of the present study, more specialized workers, such as cutters and shot-firers, and supporting craftsmen, such as electricians and engineers, have been excluded as the numbers are relatively small.

\section{Method}

Random samples were taken from each of the four groups of workers, and men from these samples were asked to attend for interview when a questionnaire was completed. Each man was asked in particular about recurring rheumatic symptoms. 
Rheumatism was defined as persistent or recurring musculo-skeletal pain without immediate traumatic cause. When such symptoms were present a simple clinical examination was made in order to localize the site and cause of the pain and to assess the presence or absence of arthritic changes. An estimate was also made of the local and general functional limitations which were caused by the symptoms.

The diagnosis was made without recourse to haematological or radiological investigations, and the complaints were grouped as follows:

(1) Disease of intervertebral disks was diagnosed in the presence of pain in the back or neck which was either recurrent or of prolonged duration and which could be accurately localized. In addition, there had to be a history of pain radiating along the distribution of a spinal root at some time, though not necessarily at every attack.

(2) Osteo-arthrosis was diagnosed when clinical evidence of degenerative joint disease affecting the limbs was observed.

(3) Rheumatoid arthritis was diagnosed in the presence of three of the six clinical criteria recommended by the American Rheumatism Association (1958).

(4) Chronic tenosynovitis was diagnosed when there had been continuous or intermittent pain on movement of a tendon within its sheath or on pressure over the sheath of at least 6 weeks' duration.

(5) Chronic bursitis was diagnosed when there was chronic, painful swelling of one of the bursae or when there had been a history of continuous or recurrent swelling of at least 6 weeks' duration.

(6) Undetermined rheumatic pain was the diagnosis applied to all musculo-skeletal pains which did not fall into one of the above categories and which could not be diagnosed as one of the definite but rare related rheumatic conditions, such as ankylosing spondylitis or gout.

The fact that other observers had found a high percentage of men with rheumatic symptoms to which no diagnostic label could be attached was noted. This may constitute a source of irritation to both rheumatologists and epidemiologists, but it was felt that attempts to counteract it by introducing disease labels such as fibrositis and myalgia would merely increase confusion. In addition to taking a general medical history and making a clinical examination, the observer inquired about the sickness absence during the previous year with particular reference to duration and cause. A record was also made of changes of job apart from those due to redundancy or dismissal. The reasons for these changes, as stated by the worker, were noted and particular attention was paid to those changes of job which resulted in a reduction of earning capacity. These inquiries about work $\frac{0}{\omega}$ history were not confined to transfers within the coal mining industry, but were also made in respect of changes made before the men became miners.

\section{Results}

Altogether 340 miners in the four specified work ${ }^{\infty}$ categories were interviewed. This represented $91 \vec{\circ}$ per cent. of the 375 men who were asked to attend. $\overrightarrow{\vec{H}}$ A study was made of the medical records of those ${ }_{\sigma}^{\omega}$ who did not see the doctor, and the available information did not indicate that these men would be $\rho$ more or less prone to rheumatic symptoms than their colleagues. Accordingly, in presenting the results, the number interviewed is assumed to be representative of the whole colliery.

\section{Prevalence of Symptoms}

Table I (opposite) shows that $160(47 \cdot 1$ per cent.) of the 340 men seen claimed to have suffered from 3 rheumatic pains during the previous 12 months;® these men have been described as "positives", $\vec{\theta}$ and of these $58(17 \cdot 1$ per cent.) said that they had symptoms at the time of interview. In additign to the positives there were forty men $(11.8$ per cen of those interviewed) who, although symptom-free during the previous 12 months, admitted having hado symptoms at some time during their working lives $; \stackrel{\circ}{\mathbb{Q}}$ these are referred to as "intermediates". The remaining $140(41 \cdot 2$ per cent.) denied having had $\vec{O}$ rheumatic symptoms since starting work ("nega- 3 tives"). The prevalence of recent symptoms in the four types of workers under discussion is also shown in Table I. The highest symptom rate was in strippers, with a crude rate of 51 per cent. positives, and the lowest was in surface workers (43 per cent.). Since one-third of those working on the surface were under 25 years of age, these crude rates may be regarded as a measure of age rather than of occupation.

In order to try to overcome this age bias, more detailed consideration has been paid to the rates for those in the older age groups (Table II, opposite). N There were 73 (57 per cent.) positives out of a total of 128 non-face workers aged 35 years and over. This rate was the same as that in face workers of $\omega$ the same age group, in whom 57 out of 100 had had symptoms during the previous year.

Even when the non-face workers were sub- $\bar{\Phi}$ divided into those who formerly worked at the coal ${ }^{\circ}$ face and those who had never done so, the rates of 


\section{EFFECTS OF RHEUMATIC DISEASES IN A MINING POPULATION \\ TABLE I}

PREVALENCE OF RHEUMATIC SYMPTOMS IN DIFFERENT CATEGORIES OF MINE WORKERS

\begin{tabular}{|c|c|c|c|c|c|c|c|c|}
\hline \multirow{2}{*}{ Occupation } & \multirow{2}{*}{. } & \multicolumn{3}{|c|}{ Face Workers } & \multicolumn{3}{|c|}{ Non-Face Workers } & \multirow{2}{*}{$\begin{array}{l}\text { All } \\
\text { Colliery } \\
\text { Workers }\end{array}$} \\
\hline & & Strippers & Brushers & All & $\begin{array}{c}\text { Underground } \\
\text { Haulage }\end{array}$ & Surface & All & \\
\hline \multirow{2}{*}{$\begin{array}{l}\text { Positive } \\
\text { (symptoms during past } \\
12 \text { months) }\end{array}$} & No. & 38 & 34 & 72 & 32 & 56 & 88 & 160 \\
\hline & Per cent. & $51 \cdot 4$ & $49 \cdot 3$ & $50 \cdot 3$ & $47 \cdot 1$ & $43 \cdot 4$ & $44 \cdot 7$ & $47 \cdot 1$ \\
\hline \multirow{2}{*}{$\begin{array}{l}\text { Intermediate } \\
\text { (symptoms since starting } \\
\text { work, but not during } \\
\text { past year) }\end{array}$} & No. & 5 & 8 & 13 & 9 & 18 & 27 & 40 \\
\hline & Per cent. & $6 \cdot 8$ & $11 \cdot 6$ & $9 \cdot 1$ & $13 \cdot 2$ & $14 \cdot 0$ & $13 \cdot 7$ & $11 \cdot 8$ \\
\hline \multirow{2}{*}{$\begin{array}{l}\text { Negative } \\
\quad \text { (no symptoms) }\end{array}$} & No. & 31 & 27 & 58 & 27 & 55 & 82 & 140 \\
\hline & Per cent. & $41 \cdot 9$ & $39 \cdot 1$ & $40 \cdot 6$ & $39 \cdot 7$ & $42 \cdot 6$ & $42 \cdot 1$ & $41 \cdot 2$ \\
\hline \multicolumn{2}{|c|}{ Totals on which Percentages are Based } & 74 & 69 & 143 & 68 & 129 & 197 & 340 \\
\hline
\end{tabular}

TABLE II

POSITIVE RHEUMATIC SYMPTOMS IN MEN OVER 35 YEARS OF AGE,* BY EMPLOYMENT

\begin{tabular}{|c|c|c|c|c|c|}
\hline \multirow{2}{*}{\multicolumn{3}{|c|}{ Employment }} & \multicolumn{3}{|c|}{ Age (yrs) } \\
\hline & & & $35-54$ & Over 55 & Total Over 35 \\
\hline \multirow{2}{*}{ Face Workers } & \multirow{2}{*}{ Strippers and Brushers } & Per cent. & $54 \cdot 4$ & $66 \cdot 7$ & $57 \cdot 0$ \\
\hline & & No. & 43 & 14 & 57 \\
\hline \multirow{4}{*}{ Non-Face Workers } & \multirow{2}{*}{ Former Face Workers .. } & Per cent. & $46 \cdot 7$ & $61 \cdot 9$ & $55 \cdot 6$ \\
\hline & & No. & 14 & 26 & 40 \\
\hline & \multirow{2}{*}{ No Face Work Experience } & Per cent. & $59 \cdot 5$ & $57 \cdot 9$ & $58 \cdot 9$ \\
\hline & & No. & 22 & 11 & 33 \\
\hline \multirow{2}{*}{ Total } & \multirow{2}{*}{$\cdots$} & Per cent. & $54 \cdot 1$ & $62 \cdot 2$ & $57 \cdot 0$ \\
\hline & & No. & 79 & 51 & 130 \\
\hline
\end{tabular}

* Numbers under 35 years of age are too small for comparison.

55.6 and 58.9 per cent. respectively for those over 35 years were reasonably constant considering the small number involved.

\section{Diagnosis}

The diagnoses, which were based on simple clinical examinations, of all those who had had symptoms at any time (i.e. positives and intermediates) are given in Table III (overleaf).

Wherever possible only one diagnostic label was attached to each man suffering from rheumatism. In five men, however, both osteo-arthrosis and disk degeneration were clearly demonstrable; in other cases only the main cause of disability was recorded.

Osteo-arthrosis, diagnosed on evidence of degenerative changes in joints of limbs, was present in fifty miners
(14.7 per cent. of those interviewed) who were examined. This form of rheumatism increased in prevalence with advancing years and was observed in $\mathbf{4 0}$ per cent. of those over the age of 55 years.

Disk disease was diagnosed in 48 miners $(14 \cdot 1$ per cent. of those interviewed). There is a suggestion that complaints of this type are commoner in middle-aged men than in those at the extremes of working life, but with the numbers available this trend is not significant statistically.

Undetermined Rheumatic Pains were reported by 88 men ( 25.9 per cent. of those interviewed).

BACK AND NECK. -53 of these men (15.6 per cent.) had symptoms referable to the back or neck, but these were so vague or so transitory that it was not considered justifiable to ascribe them to disk lesions. These 
DIAGNOSIS OF ALL SUBJECTS WITH RHEUMATIC SYMPTOMS-POSITIVES AND INTERMEDIATESAS PERCENTAGES OF NUMBERS INTERVIEWED, BY AGE

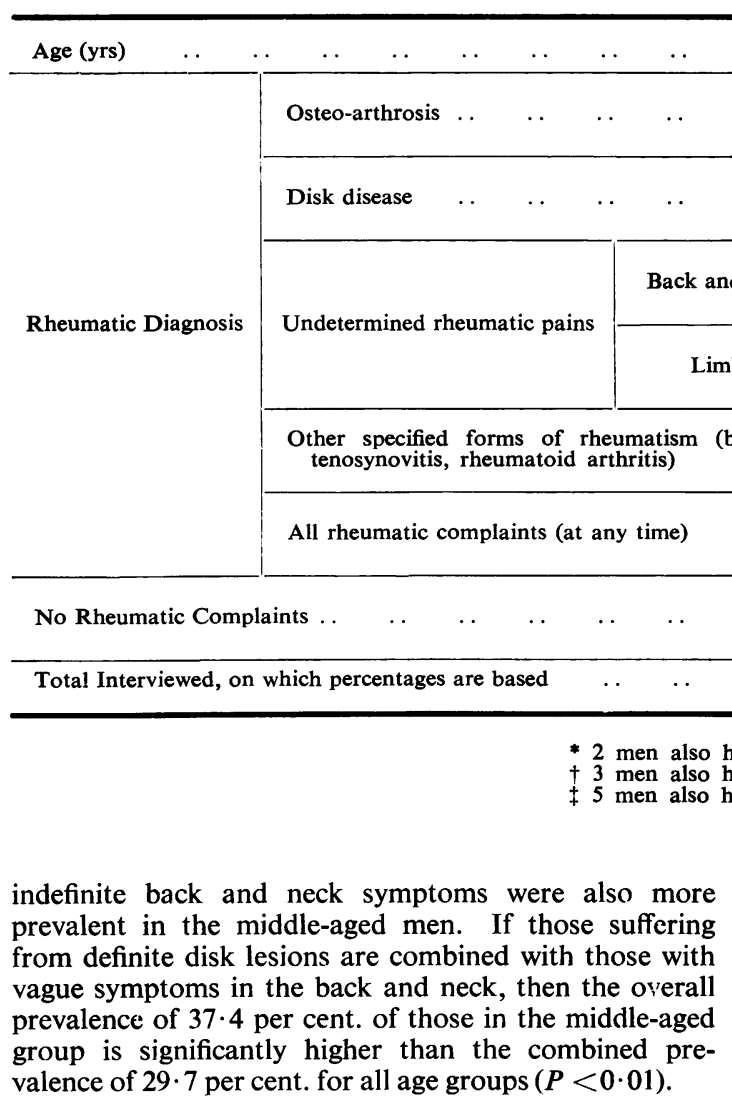

LIMBS. -35 men $(10 \cdot 3$ per cent.) had pains of undetermined origin confined to the limbs. Two-thirds of these occurred in the middle-aged group and most were dismissed as trivial by the men themselves.

Clinical Rheumatoid Arthritis was diagnosed in two cases ( 0.6 per cent.). One of them, who was aged 63 years, had been working as a stripper until one year before the interview, in spite of marked changes in his hands, elbows, and knees which had been present for up to 10 years; he had never consulted a doctor about these. The other man, who was aged 42 years, had early signs of rheumatoid arthritis, but was already finding it difficult to continue as an underground haulage worker.

Other Specified Rheumatic Diseases, all of which were chronic inflammatory conditions of the bursae or tendons, were found in seventeen men ( 5 per cent.), and the prevalence was evenly spread throughout the three age groups.

Since the numbers in Table III relate to all those who had ever had rheumatic symptoms, one mighto expect the rates to increase with age. It is possible that undetermined rheumatic symptoms of theo limbs occurring in the middle-aged might becomeo diagnosable as osteo-arthrosis in those over 55 yearse of age, but the marked drop in the rate of diagnosing $\overrightarrow{\overline{0}}$ disk disease and vague backache in the elderly 3 requires some explanation and will be discussed later.

A relationship between diagnosis and type of worko can be demonstrated in the case of osteo-arthrosis. Out of 143 face workers, sixteen $(11 \cdot 2 \text { per cent. })_{3}$ were diagnosed as having osteo-arthrosis while 35 (17.7 per cent.) of the 197 non-face workers were so diagnosed. Of the 197 non-face workers there were, however, 76 who had formerly worked at the coal face as brushers and strippers. Table IV (oppo $\frac{7}{O}$ site) shows the age prevalence when these men were grouped with the current face workers. Osteo- $N$ arthrosis was diagnosed in eleven ( $9 \cdot 1$ per cent.) of non-face workers who had never worked at the coalo face, while the same diagnosis was made in $39(17 \cdot 8 \mathrm{~W}$ per cent.) of those who had worked at the coal face at some time during their lives. This trend iso present in each of the two age groups shown ind Table IV and the difference is statistically significant. $(P<0.05)$. 
TABLE IV

PREVALENCE OF OSTEO-ARTHROSIS BY AGE AND OCCUPATION, PER 100 SUBJECTS INTERVIEWED

\begin{tabular}{|c|c|c|c|c|}
\hline \multirow{2}{*}{\multicolumn{2}{|c|}{ Occupation }} & \multicolumn{3}{|c|}{ Age (yrs) } \\
\hline & & Under 45 & $45+$ & All Ages \\
\hline \multirow{2}{*}{$\begin{array}{l}\text { Face Workers } \\
\text { and Former } \\
\text { Face Workers }\end{array}$} & Per cent. & $4 \cdot 0$ & $29 \cdot 6$ & $17 \cdot 8$ \\
\hline & No. & 4 & 35 & 39 \\
\hline \multirow{2}{*}{ Non-Face Workers } & Per cent. & $2 \cdot 6$ & $20 \cdot 9$ & $9 \cdot 1$ \\
\hline & No. & 2 & 9 & 11 \\
\hline \multirow{2}{*}{ All Miners } & Per cent. & $3 \cdot 4$ & $25 \cdot 4$ & $15 \cdot 0$ \\
\hline & No. & 6 & 44 & 50 \\
\hline
\end{tabular}

In the case of those in whom disk disease was diagnosed the trend is somewhat different (Table V). Disk lesions were diagnosed in $34(15 \cdot 5$ per cent.) of the 219 face workers and former face workers; this prevalence rate was fairly constant for each group.

The overall prevalence of disk disease in those who had never worked at the coal face was lower (11.6 per cent.). Amongst those of middleage, however, the non-face workers had a higher prevalence of symptoms suggestive of disk pathology (27.0 per cent.). This difference, though worthy of further discussion, is not significant statistically because of the small numbers involved.
TABLE V

PREVALENCE OF DISK DISEASE BY AGE AND OCCUPATION, PER 100 SUBJECTS INTERVIEWED

\begin{tabular}{|c|c|c|c|c|c|}
\hline \multirow{2}{*}{\multicolumn{2}{|c|}{ Occupation }} & \multicolumn{4}{|c|}{ Age (yrs) } \\
\hline & & $15-34$ & $35-54$ & $55+$ & All Ages \\
\hline \multirow{2}{*}{$\begin{array}{l}\text { Face Workers } \\
\text { and Former } \\
\text { Face Workers }\end{array}$} & Per cent. & $17 \cdot 0$ & $15 \cdot 5$ & $14 \cdot 5$ & $15 \cdot 5$ \\
\hline & No. & 8 & 17 & 9 & 34 \\
\hline \multirow{2}{*}{$\begin{array}{l}\text { Non-Face } \\
\text { Workers }\end{array}$} & Per cent. & $3 \cdot 1$ & $27 \cdot 0$ & $10 \cdot 5$ & $11 \cdot 6$ \\
\hline & No. & 2 & 10 & 2 & 14 \\
\hline \multirow{2}{*}{ All Miners } & Per cent. & $8 \cdot 9$ & $18 \cdot 4$ & $13 \cdot 6$ & $14 \cdot 1$ \\
\hline & No. & 10 & 27 & 11 & 48 \\
\hline
\end{tabular}

\section{Sickness Absence}

The number of weeks of sickness absence from all causes during the year before the interview was based on the memories of the workers being interviewed. In the 197 non-face workers the total sickness absence in the preceding 12 months was 625 weeks (average 3.2 per worker), and with 143 face workers it was 534 weeks (average 3.7 per worker). On the basis that each man has a potential working year of fifty weeks, this loss of time was equivalent to 6.3 and 7.5 per cent. respectively of the annual working potential.

Table VI compares the average number of weeks lost per man from non-rheumatic causes in those

TABle VI

NON-RHEUMATIC SICKNESS ABSENCE IN POSITIVES AND OTHERS, SHOWING AVERAGE NUMBER OF WEEKS OFF PER WORKER INTERVIEWED, BY AGE AND OCCUPATION

\begin{tabular}{|c|c|c|c|c|c|c|c|c|}
\hline \multirow{2}{*}{ Occupation } & \multirow{2}{*}{\multicolumn{4}{|c|}{ Symptoms }} & \multicolumn{4}{|c|}{ Age (yrs) } \\
\hline & & & & & $15-34$ & $35-54$ & $55+$ & All Ages \\
\hline \multirow{4}{*}{ Face Workers } & \multirow{2}{*}{ Positives } & Weeks off & & . & $3 \cdot 0$ & $3 \cdot 0$ & $3 \cdot 5$ & $3 \cdot 1$ \\
\hline & & No. of Men & - & . & 15 & 44 & 13 & 72 \\
\hline & \multirow{2}{*}{ Others } & Weeks off & . & . & $3 \cdot 4$ & $3 \cdot 0$ & $5 \cdot 4$ & $3 \cdot 3$ \\
\hline & & No. of Men & 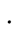 & . & 28 & 36 & 7 & 71 \\
\hline \multirow{4}{*}{ Non-Face Workers } & \multirow{2}{*}{ Positives } & Weeks off & . & . & $3 \cdot 1$ & $1 \cdot 9$ & $3 \cdot 4$ & $2 \cdot 7$ \\
\hline & & No. of Men & $\theta^{\circ}$ & . & 16 & 35 & 37 & 88 \\
\hline & \multirow{2}{*}{ Others } & Weeks off & $\cdot$ & . & $1 \cdot 8$ & $3 \cdot 6$ & $3 \cdot 0$ & $2 \cdot 5$ \\
\hline & & No. of Men & 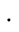 & . & 53 & 32 & 24 & 109 \\
\hline \multirow{4}{*}{ Total } & \multirow{2}{*}{ Positives } & Weeks off & 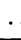 & . & $3 \cdot 0$ & $2 \cdot 5$ & $3 \cdot 4$ & $2 \cdot 9$ \\
\hline & & No. of Men & & . & 31 & 79 & 50 & 160 \\
\hline & \multirow{2}{*}{ Others } & Weeks off & & . & $2 \cdot 4$ & $3 \cdot 2$ & $3 \cdot 7$ & $2 \cdot 9$ \\
\hline & & No. of Men & & . & 81 & 68 & 31 & 180 \\
\hline
\end{tabular}


with positive rheumatic symptoms (160 men) and the others $(180 \mathrm{men})$. The time lost by the face workers $(3 \cdot 1$ weeks each for the positives and 3.3 weeks each for the rest) is greater than that lost by the non-face workers $(2 \cdot 7$ and $2 \cdot 5)$, but the average for all workers $(2 \cdot 9)$ is the same for men with rheumatism as for those without. There is, therefore, no evidence that the presence of rheumatic symptoms may increase the duration of sickness absence from non-rheumatic causes.

The same Table demonstrates that the diagnosis of rheumatism is not loosely applied to an illness as an alternative to some other label, so that time lost to industry from conditions described as rheumatic must be added to the total sickness absence from other causes.

Rheumatic illness was estimated to account for 172 weeks of absence, 51 weeks for every 100 interviewed (Table VII), and 108 of these 172 weeks (63 per cent.) were lost by those suffering from disk disease. An important contribution to sickness absence rates was made by this form of rheumatism in young face workers ( 65 weeks per 100 interviewed)? and middle-aged former face workers (130 weeks per 100 interviewed). Of the remaining 64 weeks of ? absence from rheumatism, 35 weeks (10 per $10 \overline{\mathrm{g}}$ interviewed) were caused by osteo-arthrosis, al $\overline{\underline{c}}$ in men over 35 years of age.

The relative importance of rheumatism as a cause of sickness absence is shown in Table VIII. Rheu matism accounted for 15 per cent. of all sicknessabsence sustained by the whole group, and when the age groups were considered together there was now difference between face workers and other workers in this respect. When, however, the worker's age was taken into consideration, a different patternu emerged. Rheumatism was responsible for $20 \cdot \overrightarrow{3_{\phi}}$ per cent. of sickness absence in face workers undeiw the age of 35 years and for only 2.0 per cent. ir non-face workers of the same age $(P<0.01)$.

\section{TABLE VII}

WEEKS OF ABSENCE DUE TO RHEUMATISM PER 100 WORKERS INTERVIEWED, BY AGE, DIAGNOSIS, AND OCCUPATION

\begin{tabular}{|c|c|c|c|c|c|c|c|c|c|c|c|c|c|c|c|c|c|}
\hline \multirow{2}{*}{\multicolumn{2}{|c|}{ Occupation }} & \multirow{2}{*}{\multicolumn{4}{|c|}{ Face Workers }} & \multicolumn{8}{|c|}{ Non-Face Workers } & \multirow{2}{*}{\multicolumn{3}{|c|}{ Total }} & \\
\hline & & & & & & \multicolumn{4}{|c|}{ Formerly Face Workers } & \multicolumn{4}{|c|}{ No Face Work Experience } & & & & \\
\hline Age (yrs) & $\cdots$ & $15-34$ & $35-54$ & $55+$ & $\begin{array}{c}\text { All } \\
\text { Ages }\end{array}$ & $15-34$ & $35-54$ & $55+$ & $\begin{array}{c}\text { All } \\
\text { Ages }\end{array}$ & $15-34$ & $35-54$ & $55+$ & $\begin{array}{c}\text { All } \\
\text { Ages }\end{array}$ & $15-34$ & $35-54$ & $55+$ & $\begin{array}{c}\text { Aft } \\
\text { Ages }\end{array}$ \\
\hline $\begin{array}{c}\text { Total No. } \\
\text { viewed }\end{array}$ & $\begin{array}{cc}\text { of Men Inter- } \\
\ldots\end{array}$ & 43 & 80 & 20 & 143 & 4 & 30 & 41 & 75 & 65 & 37 & 20 & 122 & 112 & 147 & 81 & 340 ํํำ \\
\hline \multirow{4}{*}{$\begin{array}{c}\text { Weeks of } \\
\text { Absence } \\
\text { per } 100 \\
\text { Inter- } \\
\text { viewed }\end{array}$} & $\begin{array}{l}\text { Osteo- } \\
\text { arthrosis .. }\end{array}$ & 0 & 22 & 0 & 13 & 0 & 10 & 27 & 19 & 0 & 8 & 0 & 2 & 0 & 16 & 14 & $10 \overrightarrow{\overline{7}}$ \\
\hline & Disk Disease & 65 & 6 & 30 & 27 & 0 & 130 & 32 & 69 & 5 & 41 & 15 & 14 & 28 & 37 & 27 & $32 \frac{0}{3}$ \\
\hline & $\begin{array}{l}\text { Other } \\
\text { Rheumatic } \\
\text { Complaints } \\
\end{array}$ & 19 & 12 & 0 & 13 & 0 & 3 & 0 & 1 & 0 & 8 & 0 & 6 & 7 & 15 & 0 & 9 \\
\hline & $\begin{array}{l}\text { All } \\
\text { Rheumatic } \\
\text { Complaints }\end{array}$ & 84 & 40 & 30 & 54 & 0 & 143 & 59 & 89 & 5 & 57 & 15 & 22 & 35 & 68 & 41 & $51 \frac{\bar{\sigma}}{3}$ \\
\hline
\end{tabular}

TABLE VIII

WEEKS OF ABSENCE DUE TO RHEUMATISM AS A PERCENTAGE OF TOTAL SICKNESS ABSENCE, BY OCCUPATION AND AGE

\begin{tabular}{|c|c|c|c|c|c|c|}
\hline Age (yrs) & . & . & $15-34$ & $35-54$ & $55+$ & All Ages \\
\hline \multirow{6}{*}{ Occupation } & \multirow{2}{*}{ Face Workers } & $\begin{array}{lll}\text { Per cent. } & \ldots & \ldots\end{array}$ & $20 \cdot 3$ & $13 \cdot 5$ & $6 \cdot 7$ & $14 \cdot 6$ \\
\hline & & No. of Weeks Off .. & 36 & 36 & 6 & 78 \\
\hline & \multirow{2}{*}{ Non-Face Workers } & Per cent. $\quad \ldots$ & $2 \cdot 0$ & $26 \cdot 1$ & $11 \cdot 7$ & $15 \cdot 0$ \\
\hline & & No. of Weeks Off. & 3 & 64 & 27 & 94 \\
\hline & \multirow{2}{*}{ Total } & $\begin{array}{lll}\text { Per cent. } \quad \ldots & \ldots\end{array}$ & $11 \cdot 9$ & $19 \cdot 5$ & $10 \cdot 3$ & $14 \cdot 8$ \\
\hline & & No. of Weeks Off .. & 39 & 100 & 33 & 172 \\
\hline
\end{tabular}




\section{Change of Job}

Seven men stated that they had changed their jobs at some time in their lives because of rheumatism, and a further fourteen declared at the time of interview that they wanted to change for the same reason. Ten (48 per cent.) of these 21 men, who were diagnosed as suffering from disk disease, represented 20.8 per cent. of the 48 miners diagnosed as having disk disease. In contrast to this, only eleven ( 7.2 per cent.) of the 152 men with other forms of rheumatism stated that they had either changed jobs or desired to do so because of rheumatic symptoms (Table IX). The numbers involved are small, but the difference between the two groups is significant $(P<0 \cdot 02)$.

In addition to the seven men who gave rheumatism as a reason for changing their jobs, there were a further 74 men who had changed jobs with loss of income when neither redundancy nor dismissal was the cause. There were thus 81 of those interviewed who had voluntarily changed jobs to the detriment of their earning capacity and who admitted that health was the reason for the change. All these men were over 25 years of age. Table X shows that 182 men over 25 years of age admitted to having had rheumatism at some time in their lives and that 58 ( 32 per cent.) of these had changed jobs with loss of income. In contrast to this, 23 ( 25 per cent.) of a total of 91 men over 25 years of age without rheumatism had changed with a similar lowering of financial status. The difference between the two groups, however, is not significant with the numbers available for consideration.

\section{Discussion}

Lawrence and Aitken-Swan (1952) and Cobb, Thompson, Rosenbaum, Warren, and Merchant (1956) have discussed the problems presented by asking a series of individuals whether or not they had any rheumatic symptoms. The first authors indicated that a single observer or two observers working closely together could obtain reasonably consistent and similar prevalence rates. Cobb and his coworkers on the other hand suggested that, even though individual observers may be consistent, one could expect variation between different observers with different interests.

Our finding that 17 per cent. of those interviewed

TABLE IX

CHANGE OF JOB BECAUSE OF RHEUMATISM, BY DIAGNOSIS

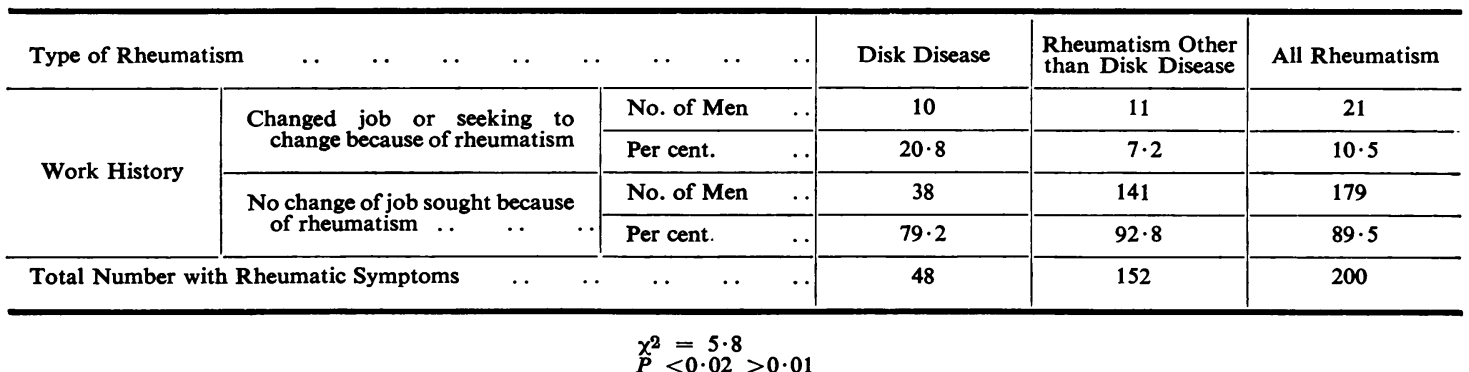

TABLE X

HISTORY OF CHANGE OF JOB IN MEN OVER 25 YEARS OF AGE WITH AND WITHOUT RHEUMATISM

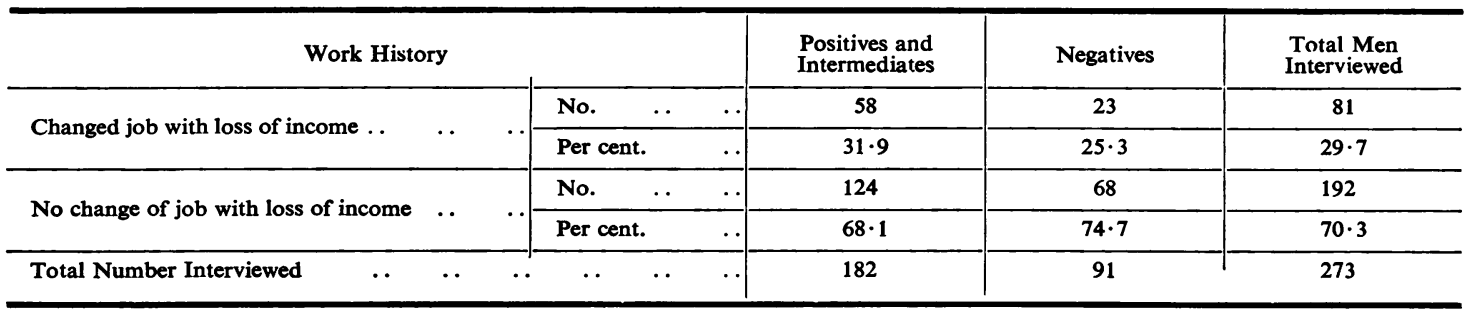


had symptoms at the time of interview compares quite closely with the figure 19 per cent. reported by Kellgren and others (1953). We would agree with their opinion that the presence or absence of symptoms at a point in time is only of limited value in a group of diseases which fluctuate in severity. For this reason we have regarded those who have had symptoms during the past year as being currently affected, and our findings indicate an overall prevalence of 44 per cent. of positives, which is significantly higher than the findings of the previous workers, who reported that 32 per cent. of miners and 25 per cent. of non-miners who were seen had had symptoms in the 5 years before interview.

The reason for the higher prevalence of recent symptoms can only be speculative. There may be a true difference between the two collieries, but difference in technique between the two sets of observers must be reckoned to play a large part in causing such discrepancies. Even if the observers had been the same it is possible that the passage of 10 years since the previous work was done might have led to a change of emphasis by both the observers and the men themselves. Whatever the reasons for the difference between the two inquiries, there seems little doubt that rheumatic symptoms in general have a high prevalence in the mining population.

The distribution of diagnoses among those who had had rheumatic symptoms at any time in their lives (positives and intermediates) was very similar to that found by previous observers, and confirms that rheumatoid arthritis, though causing major social difficulties to some individual sufferers, does not constitute a serious problem in a group of miners. This could be due to the fact that the prevalence of rheumatoid arthritis is low in males. Lawrence (1961) has summarized his findings in the Leigh population and by applying his figures to the national population he suggests that the prevalence of rheumatoid arthritis in males of working age in Scotland might be about 2 per cent. The present report that 0.6 per cent. of the miners had clinical evidence of rheumatoid arthritis may indicate that potential rheumatoid sufferers do not become coal miners, or that the disease leads to migration from the industry to other work or to the Unemployment Register.

Osteo-arthrosis has been shown to be commoner in older men. This finding is in keeping with the generally accepted view that the condition is caused by a degenerative process. Kellgren and Lawrence (1952) have shown that the radiological changes of osteo-arthrosis are commoner in miners than in non-miners, and we have observed that the condition can be diagnosed more commonly in those who have worked at the coal face than in those who have neves. been so employed. This supports the view that. prolonged and continuous heavy manual work? increases the incidence of osteo-arthrosis.

Disk disease occurring either recently or some years before the interview was not diagnosed as frequently in the oldest age group as in the middlea aged group. This is surprising in view of the facts that miners who have symptoms in middle age should still give a history of these in later life, even though the symptoms themselves have settled. It is pos $\vec{\omega}$ sible that older men forget about symptoms whicl they had some years previously and this migh: account for the anomaly, but another explanation

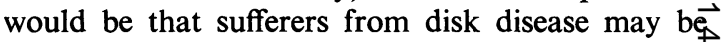
obliged to leave the colliery and seek employmentw elsewhere. The high rate of complaints due to disk disease among older men who had never workecf at the coal face may therefore be only a relativeincrease since their colleagues who worked at th\& coal face may have had to leave the colliery. Unfor tunately, a retrospective study of the medical records to discover the reason for the departure would now disclose the complete picture, since there is no longer any obligation on a worker to use ill-health as क justification for changing his job. However, a sturaty of existing records might shed light on this point

Before using sickness absence to assess the socias effects of rheumatism, it is necessary to establisto that absence which is ascribed to rheumatism is not merely replacing sickness absence from othep causes. The annual sickness absence from non $\vec{\circ}$ rheumatic causes was equal in both positives and others. There would, therefore, seem to be reason? able grounds for assuming that rheumatism was. not merely a substitute illness, but that it accounted for an annual loss of 51 weeks' work for every $10 \%$ interviewed over and above the loss caused by othes diseases.

The bulk of sickness absence from rheumatism was caused by disk disease, particularly in thê younger face worker and the middle-aged non-face worker who had formerly worked at the coal faces This pattern emphasizes the importance of disk. disease as a cause of socio-economic hardship. The next most important cause of sickness absence from the rheumatic group of diseases was osteo-arthrosi of the limb joints. This condition became increas $\omega$ ingly prevalent with advancing years, especially is those who had worked at the coal face at some time in their lives. In spite of this the sickness absence्ह from osteo-arthrosis did not show a corresponding? increase with age. One possible explanation could 
be that the severely affected patients may have had to leave the colliery entirely, as was suggested in the case of those with disk disease.

Apart from the loss of earnings from sickness absence, an illness can effect the social status of the individual by causing him to take a less well-paid job. We were unable to demonstrate statistically that rheumatism was more important than other conditions in leading to such a change of job. Nevertheless, the figures indicates that rheumatism is an important factor in contributing to such changes; how important could only be ascertained by going outside the colliery and taking into account those who are working in other industries or who are unemployed. The importance of disk disease in change of job has been suggested by the figures available, but further studies of those who have left the coal mining industry are needed before a full appreciation can be made.

It is only after establishing the relative importance of the different types of rheumatic complaints that one can demonstrate the significance of these complaints in loss of earning power. This loss or reduction of income is a fundamental point in considering the social effects of rheumatism, and for this reason, in our initial study, we have confined ourselves to considering the prevalence, sickness absence, and changes of job in relation to rheumatism. Further exploration is required before assessing the interaction of employer, job, and workmates on the one hand and an employee with rheumatic symptoms on the other.

\section{Summary}

(1) The prevalence of rheumatic symptoms in workers in a Scottish coal mine was assessed. It was found that 47 per cent. of those interviewed had had symptoms during the previous year.

(2) Osteo-arthrosis becomes more prevalent with advancing years. Even allowing for this, however, it has been shown to be commoner in those who have worked at the coal face.

(3) Sickness absence due to rheumatic diseases was 51 weeks per 100 workers per year. Miners with rheumatic complaints suffered the same loss of work from other forms of illness as did those without rheumatic symptoms.

(4) Disease of the intervertebral disks caused 63 per cent. of the absence from rheumatic causes. The possible role of disk disease in leading to change of employment has been demonstrated.

We wish to express our gratitude to the Empire
Rheumatism Council, who are financing this project, and to Miss Christine Bell, secretary to the Unit.

We should also like to thank Dr. Gooding, Dr. Watson, and Mr. McCormack, S.R.N., of tne Medical Section of the Scottish Coal Board, the representatives of the local branch of the National Union of Mineworkers, and the Manager of the Woolmet Colliery for their help and interest.

\section{REFERENCES}

American Rheumatism Association (1958). Bull. rheum. Dis., 9, 175.

Brown, R., and Lingg, C. (1961). Arthr. and Rheum., 4, 283.

Cobb, S., Thompson, D. J., Rosenbaum, J., Warren, J. E., and Merchant, W. R. (1956). J. chron. Dis., 3, 134.

Department of Health for Scotland (1945). "Chronic Rheumatic Diseases." Report of the Medical Advisory Committee (Scotland). H.M.S.O., Edinburgh.

Duthie, J. J. R., and Anderson, J. A. D. (1962). Arch. environm. Hlth, 4, 511.

Kahlmeter, G. (1923). Acta med. scand., 59, 153.

Kellgren, J. H., and Lawrence, J. S. (1952). Brit. J. indust. Med., 9, 197.

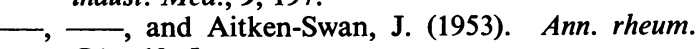
Dis., $12,5$.

Lawrence, J. S. (1961). Ibid., 20, 11.

and Aitken-Swan, J. (1952). Brit. J. industr. Med., 9, 1.

Ministry of Health (1924). "The Incidence of Rheumatic Diseases." Reports on Public Health and Medical Subjects, No. 23. H.M.S.O., London.

Ministry of Pensions and National Insurance (1956). "Digest of Statistics analysing Certificates of Incapacity, 1955-56." H.M.S.O., London.

Effets sociaux et économiques des maladies
rhumatismales dans une population minière

RÉSUMÉ

(1) On procéda à l'évaluation de la fréquence des symptômes rhumatismaux chez des mineurs d'une houillère écossaise. On trouva que $47 \%$ de ceux interrogés avaient accusé des symptômes au cours de l'année précédente.

(2) Avec l'âge, l'ostéoarthrite devient plus fréquente, mais tout en prenant cela en considération, elle est encore plus commune chez des mineurs.

(3) L'absence du travail due aux maladies rhumatismales s'éléva à 51 semaines par 100 mineurs par an. Les mineurs présentant des affections rhumatismales perdirent autant de temps de travail à cause d'autres maladies que ceux sans symptômes rhumatismaux.

(4) L'affection du disque intervertebral occasionna $63 \%$ des absences pour causes rhumatismales. On 
avait déjà démontré le rôle probable de la maladie du disque comme cause d'un changement d'occupation.

\section{Efectos sociales y económicos de las enfermedades reumatoides en una población minera}

\section{SUMARIO}

(1) Se determinó la frecuencia de síntomas reumáticos ne mineros de una carbonera escocesa. Se encontró que un $47 \%$ de los interrogados habían manifestado tales síntomas en el curso del año anterior.

(2) Con avanzar la edad, la osteoartritis se ve más a menudo, pero aún tomando esto en consideración, frecuencia es mayor en los mineros.

(3) La ausencia del trabajo debida a enfermedades reumatoides fué de 51 semanas por 100 mineros po año. Los mineros con afecciones reumáticas perdieron tanto tiempo de trabajo por causa de otras enfermedade como los sin síntomas reumáticos.

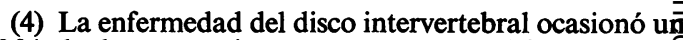
$63 \%$ de las ausencias por causas reumáticas. Ya habia demostrado el papel probable de la enfermedaê del disco como causa del cambio de ocupación. 